\title{
Retracted: Iterative Schemes by a New Generalized Resolvent for a Monotone Mapping and a Relatively Weak Nonexpansive Mapping
}

\author{
Journal of Applied Mathematics \\ Received 14 July 2014; Accepted 14 July 2014; Published 17 July 2014 \\ Copyright (C) 2014 Journal of Applied Mathematics. This is an open access article distributed under the Creative Commons \\ Attribution License, which permits unrestricted use, distribution, and reproduction in any medium, provided the original work is \\ properly cited.
}

This article in [1] has been retracted as it is essentially identical in content with a previously published paper by the same authors titled "A New Generalized Resolvent and Application in Banach Mappings." This manuscript was published in East Asian Mathematical Journal, Volume 30 (2014), No. 1, pp. 6977.

\section{References}

[1] X. Wang, J. Chen, and H. Tong, "Iterative schemes by a new generalized resolvent for a monotone mapping and a relatively weak nonexpansive mapping," Journal of Applied Mathematics, vol. 2014, Article ID 603186, 6 pages, 2014. 